\title{
Assessment of flushing methods for the removal of heavy chlorinated compounds DNAPL in an alluvial aquifer
}

\author{
Julien Maire ${ }^{\mathrm{a}}$, Antoine Joubert ${ }^{\mathrm{b}}$, Delphine Kaifas ${ }^{\mathrm{c}}$, Thomas Invernizzi ${ }^{\mathrm{b}}$, Julien Marduel ${ }^{\mathrm{b}}$, Stéfan Colombano ${ }^{\mathrm{d}}$, \\ David Cazaux $^{\text {e }}$, Cédric Marion ${ }^{\mathrm{e}}$, Pierre-Yves Klein ${ }^{\mathrm{c}}$, Alain Dumestre ${ }^{\mathrm{b}}$, Nicolas Fatin-Rouge ${ }^{\mathrm{a}, *}$ \\ a Institut UTINAM, Université de Bourgogne Franche-Comté, 16 Route de Gray, 25000 Besançon, France \\ b SERPOL, 2 Chemin du Génie, 69633 Vénissieux, France \\ ' Sol Environment, 22 Rue Lavoisier, 92000 Nanterre, France \\ d BRGM, 3 Avenue Claude Guillemin, 45060 Orléans, France \\ e Inovyn, Avenue de la République, 39500 Tavaux, France
}

\begin{abstract}
Immiscible mobilization and foam flushing were assessed as low surfactant consuming technologies, for the enhanced recovery of dense non-aqueous phase liquid (DNAPL) residual at a site contaminated by heavy chlorinated compounds. Preliminary experiments in well-controlled conditions demonstrated the phenomena involved in these remediation technologies and their limitations. Furthermore, we characterized the technologies according to by their surfactant consumption (per $\mathrm{kg}$ of DNAPL recovered) and the final DNAPL saturation reached. Surfactant foam flushing (SFF) produced lower DNAPL saturation than immiscible mobilization, thanks to its higher viscosity. However, its efficiency is strongly correlated to the pressure gradient $(\nabla \mathrm{P})$ used during injection, and that is limited by risks of soil fracturing. The two technologies were tested in field cells $(10 \mathrm{~m} \times 10 \mathrm{~m} \times 10 \mathrm{~m})$ delimited by cement/ bentonite walls anchored in the clayey substratum. The deepest soil layer was the most contaminated. It was composed of silt-sandy soil and had an average hydraulic conductivity of $10^{-4} \mathrm{~m} \mathrm{~s}^{-1}$. Field results show that we should now model flushing fluid propagation to design efficient set-ups for recovering the displaced DNAPL.
\end{abstract}


Chlorinated organic compounds (COCs) have been released for decades into the environment because of use in anthropogenic activities like chemistry, pharmacy and agriculture (Académie des Sciences, 2000; Hildenbrand et al., 2016, 2015). COCs are widespread contaminants in soil and groundwater because of their low degradability and, for the lightest and most polar compounds, their relatively high water solubility. The presence of dense non-aqueous phase liquids (DNAPLs) of COCs in these media is the result of spillages. These DNAPLs percolate to the aquitard because of their high density and low solubility. As the free phase moves downwards, it leaves behind a discontinuous residual phase of compounds in the contaminated soils. There, DNAPL droplets are trapped by capillary forces in narrow soil pores. However, the water permeability of the contaminated strata increases as water saturation. Pure and residual phases feed plumes of dissolved COCs for the long term, which may prevent water use because of drinking water and indoor air standards (Ireland Environmental Protection Agency, 2014; WHO, 2010).

Source zones of COCs are a serious environmental liability, since they are challenging to remediate (Interstate Technology and Regulatory Council, 2002; Stroo et al., 2012). Pump and treat (PT) technology is commonly used for DNAPL treatment, but typical recovery rates do not exceed $60 \%$ even at their highest values (Interstate Technology and Regulatory Council, 2002). Indeed, because of DNAPL's high density, low solubility and high interfacial tension with water $\left(\gamma_{o w}\right)$, PT is not effective for mass removal (National Research Council, 1994). Older PT technology has progressively moved from targeting source zone containment to remediation through the surfactant-enhanced aquifer remediation (SEAR) approach, whereas in the meantime in situ chemical oxidation (ISCO) or reduction (ISCR) or biodegradation have been developed for plume treatment of non-volatile COCs (Scherer et al., 2000). Surfactant flushing is used to manage low saturation index of the organic phase i.e. the residual phase. Surfactant flood increases the DNAPL removal through three mechanisms: 1) mobilization owing to $\gamma_{\text {ow }}$ reduction that arises when surfactant concentration $\left(C_{S}\right)$ is lower than its critical micellar concentration (CMC), 2) emulsification, like microemulsion phases for $\mathrm{C}_{\mathrm{S}} \sim \mathrm{CMC}$ and 3 ) dissolution of contaminants into micelles that arises when $C_{S}$ exceeds the CMC-value in pores (Paria, 2008; Rosen, 2004). Mobilization starts when the sum of viscous and buoyancy forces exceeds the capillary forces of the contaminated medium (Duffield et al., 2003; Jeong, 2005; Li et al., 2007; Pennell et al., 1996). However, this strategy is controversial because of the risks associated to the uncontrolled sinking of DNAPLs beyond the influence zones of extracting wells and penetration in less permeable zones (Rathfelder et al., 2003; Robert et al., 2006). Microemulsions with sizes about $100 \mathrm{~nm}$ are smaller than the average pore sizes of permeable soil material and travel quite freely. However, to produce them in situ requires tedious lab work to build up the required complex phase diagrams and often needs the addition of large amounts of inorganic salts (Martel et al., 1993; Szafranski et al., 1998). Moreover, the low surfactant to COC ratio (typically ranging from 15 to $30 \%$ ) may lead to dense plume sinking beyond the influence of extracting wells (Oostrom et al., 1999; Robert et al., 2006). Finally, dissolving COCs in micelles is unpopular, because of the large amounts of surfactant required, considering the low surfactant solubilization capacity values (Butler and Hayes, 1998; Damrongsiri et al., 2010) and the huge amount of highly contaminated wastewater with water stabilized pollutants that requires the use of costly purification technologies (Ahn et al., 2010, 2008, 2007; Lee et al., 2005; Sabatini et al., 1998).

The limitations of the above technologies for soil flushing are acknowledged (Atteia et al., 2013; Szafranski et al., 1998; Taylor et al., 2001), because of the reasons given and soil anisotropy (both in terms of geology and pollution). The need for increased viscous pressure of the injected phase to overcome trapping forces is well documented and has boosted the use of polymer solutions and surfactant foams (SF) in enhanced oil recovery processes (Jeong, 2005; Lake, 1989). The basic concept for making in situ mobility control with foams is to inject gas with a surfactant solution. Many studies report fundamental knowledge about mechanisms involved in foam generation and propagation in pores of homogeneous and heterogeneous soils (Bertin et al., 1998; Kovscek and Radke, 2009). Foam in porous media appears as gas bubbles separated by thin liquid films (lamellae) blocked at pore throats. These lamellae must stretch to go through pores or break, opposing resistance to gas flow. This gives an important apparent viscosity to the foam that diverts flow from big pores to smaller ones. Hence, foam can be used in two ways: firstly, as a blocking agent. Foam is used to block high permeability zones to improve treatment fluid sweeping in low permeability zones; or, secondly, as a mobility control agent. Foam is used as the treatment fluid, since it will propagate at the same velocity in all permeability zones (Bertin et al., 1998; Khatib et al., 1988). However, this approach is less popular than injecting a polymer solution, because foam's mobility is less predictable. Nevertheless, SF is potentially more efficient than polymer flushing to remove nonaqueous phase liquids and significant progress has been made in the last decade.

In situ environmental remediation (ISER) using foam has similarities with EOR, but also major differences: on the one hand, EOR takes place thousands of meters below ground surface (bgs) and average recovery yields reach only 20-40\% (Muggeridge et al., 2013); on the other hand, ISER occurs only some meters bgs and remaining contaminants should be at the ppm level or less (Kilbane et al., 1997). Hence ISER is more challenging, requiring low pressure injection to avoid soil fracturing (about $100 \mathrm{kPa} \mathrm{m}^{-1}$ of depth ("Hydraulic Fracturing Technology Technology Evaluation Report", 1993)) while requiring better sweeping efficiency. In previous articles (Maire et al., 2015; Maire and Fatin-Rouge, 2017), authors proved the efficiency of SF flushing to mobilize a DNAPL pool of heavy and biorecalcitrant COCs ahead of recovery wells in a saturated soil with minimal dissolution and low pressure gradient $(\nabla \mathrm{P})$. The surfactant alternating gas (SAG) mode of injection was selected to avoid soil fracturing. The SAG technology is recent and most of the literature still describes the use of co-injection process (Shokrollahi et al., 2014). SAG aims to maintain good foam injectability where continuous gas and solution injection (pre-made foam or coinjection foam) can lead to blockage (Blaker et al., 2002). During this process, solution and gas slugs are injected alternately. This process allows for a strong foam front (required to avoid gravity override) and low $\nabla \mathrm{P}$ for propagation because foam between front and injection well foam collapses during gas injection (Farajzadeh et al., 2015). The gas and solution slugs' ratio is the most critical parameter for a successful SAG (Salehi et al., 2014). It should be finely tuned for each application to avoid the fingering of weak foam through strong foam front.

The need to document and quantify how new DNAPL treatment technologies perform has been stated repeatedly since the early nineties. This study investigates the use of SF flood to remove a residual phase of heavy and recalcitrant chlorinated compounds from a contaminated alluvial aquifer. To the best of our knowledge, the only field assessment of foam ISER used a SAG process to generate foam in an anisotropic geology (Hirasaki et al., 1997). Foam was used as a blocking agent that was formed in the most permeable horizon to divert a surfactant solution to a less permeable horizon where the DNAPL was. Our approach uses the foam differently, as the mobile phase for pure phase COCs recovery in a homogenous horizon. Here, we have compared the SF flood performance with some surfactant flood technologies wellknown both at lab- and field-scales.

\section{Materials and methods}

\subsection{Study site}

The Tavaux site is a large chloralkali chemical plant located in the center-east of France. From the 1980s to 2007, a historical DNAPL pool of several hectares was physically confined by pumping while migration was monitored. The DNAPL rapidly migrated from a landfill and reached a static state within a shallow water-table sandy aquifer at top of a 
clayey substratum $10 \mathrm{~m}$ bgs. The DNAPL pool thickness was observed to be from $20 \mathrm{~cm}$ to $150 \mathrm{~cm}$ according to substratum morphology.

In the context of the SILPHES project, four concrete cubic cells were dug above the DNAPL source zone, confining a part of the DNAPL pool thanks to cement/bentonite walls (trenches of mixed soils).

\subsection{Chemicals}

We used dihexylsulfosuccinate (DHSS) as the surfactant (Aerosol MA-80, Cytec, anionic, $80 \%$, CMC $=1.5 \%$ of commercial product or $1.2 \%$ DHSS). It was used as received from the producer. It was primarily selected for its ability to make foam when foam is generated in porous medium using the SAG process. It was also able to efficiently lower the interfacial tension between DNAPL and water $\left(\gamma_{o w}\right)$. Consequently, we used it to mobilize the residual DNAPL phase at lab- and field-scales.

\subsection{Lab studies}

\subsubsection{Soil, water and contaminant}

The soil was collected at the study site, upstream from the contaminated area, in the same alluvial geological layer as the one in which the DNAPL laid. The raw soil was sieved under running water to collect a selected fraction between 0.08 and $2.5 \mathrm{~mm}$ for the experiments. The porosity of the selected material was $35 \%$, its intrinsic permeability was $40 \mu \mathrm{m}^{2}$. The natural organic content of the soil was found to be insignificant.

The ionic composition of water is known to affect $\gamma_{\text {ow }}$. Hence, for lab-trials to be representative of field conditions, an artificial groundwater was prepared by dissolving $0.039 \mathrm{~g}$ of $\mathrm{MgCl}_{2}$ and $0.914 \mathrm{~g} \mathrm{CaCl}_{2}$ in $1 \mathrm{l}$ of deionized water, based on the ionic balance of the site's groundwater. Surfactant solutions were prepared with this artificial groundwater.

Soil samples were contaminated by the black DNAPL pumped from the site. The DNAPL density was $1.6 \mathrm{~g} \mathrm{~cm}^{-3}$. Its main components were hexachlorobutadiene (58\%), hexachloroethane (16\%), perchloroethylene (8\%), and pentachlorobenzene (3.5\%). Additional information about soil and contaminant characteristics can be found elsewhere (Maire et al., 2015).

\subsubsection{Interfacial tension measurement}

The IFT between DNAPL and aqueous phase $\left(\gamma_{\mathrm{ow}}\right)$ was measured for DHSS solutions with concentration varying from 0 to $1.5 \%$ by the pendant drop method. Details are given elsewhere (Maire and FatinRouge, 2017).

\subsubsection{Immiscible mobilization experiments}

A vertical glass column $(\mathrm{L}=9 \mathrm{~cm}$, i.d. $=2.5 \mathrm{~cm}$, Fig. 1$)$ was filled with a known amount of DNAPL (15 ml). Dry soil was added and compacted into the DNAPL so that the soil was fully saturated with DNAPL. Since field objectives were to extract the DNAPL at the deepest point of the clayey substratum, the main driving force being gravity, we decided for lab experiments to hold the 1D-column vertically and inject solution at the top while recovering DNAPL at the bottom. The cell outflow was directed to a phase separator to quantify the amount of DNAPL recovered. Several DHSS solutions with concentration varying from 0 to $1.5 \%$ were injected successively. Each solution was injected until the amount of DNAPL recovered stopped increasing, with a minimum of $10 \mathrm{PV}$. Solution injection was carried out using two syringe pumps (Pilot A2, Fresenius). Injection Darcy's velocity (U) was set to 1.25 $\times 10^{-4} \mathrm{~m} \mathrm{~s}^{-1}\left(\mathrm{U}_{\text {pore }}=3.58 \times 10^{-4} \mathrm{~m} \mathrm{~s}^{-1}\right)$ to match the expected injection velocity used in field-tests.

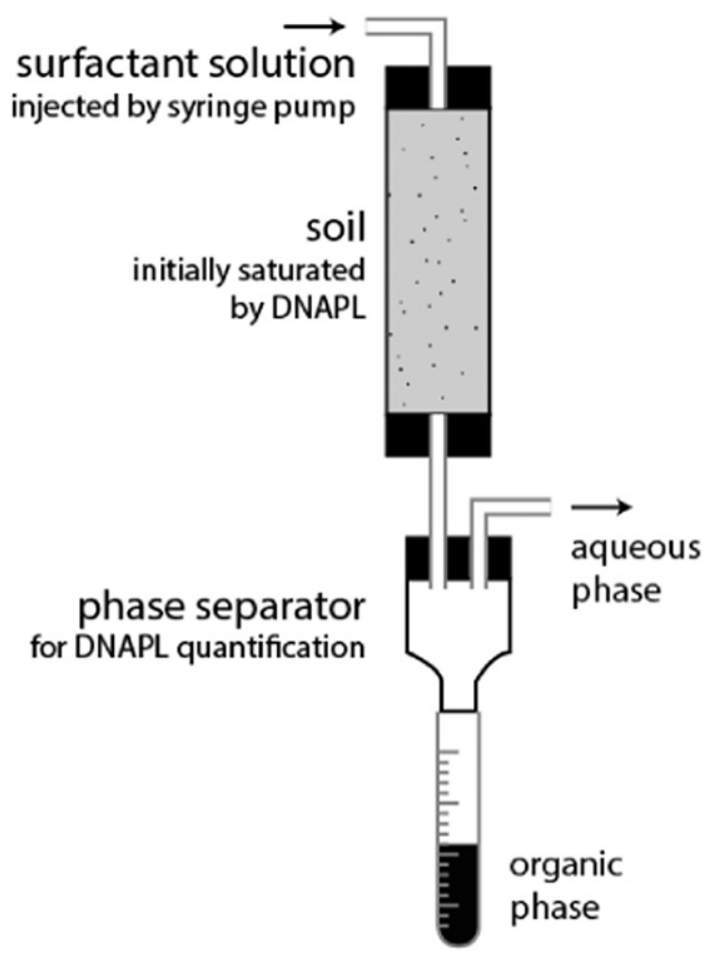

Fig. 1. Experimental set-up.

\subsection{Field tests set-up}

\subsubsection{Flushing with groundwater and with surfactant solutions}

One of the four cells was used to assess immiscible mobilization by surfactant flushing on DNAPL impregnated sands at the bottom of the aquifer (Fig. 2). The first treatment step initiated in this cell was "upwelling" PT, described by (Cazaux et al., 2014). "Up-welling” PT consists in pumping groundwater in the central recovery well (HDPE, $d=$ $170 \mathrm{~mm}$ ), creating a hydraulic pressure decrease, and reinjecting this water at the bottom of the four wells (HDPE, $d=80 \mathrm{~mm}$ ) located in each corner of the cells, creating a hydraulic pressure increase and a convective hydraulic pressure toward the recovery well. Packers were settled in the injection wells $9 \mathrm{~m}$ bgs and water pumping in recovery well was also settled in this horizon to force, as far as possible, water circulation at the bottom of the aquifer. The waterflow was fixed around $5 \mathrm{~m}^{3} \mathrm{~h}^{-1}$. This recirculating configuration aimed at accumulating all free mobile DNAPL in the recovery well equipped with a $2.5 \mathrm{~m}$ deep sediment trap anchored into the clayey substratum. Therefore, the accumulated DNAPL was pumped by a pneumatic device. In one month, free mobile DNAPL was pumped using this up-welling PT technology up to a technical limit (asymptotic recovery was reached) ending the first treatment step.

Then surfactant flushing was launched to decrease the residual DNAPL as far as possible. A dosimetric pump for surfactant injection was added to the pumping and reinjection system used for the upwelling PT technique and the waterflow was decreased to $2 \mathrm{~m}^{3} \mathrm{~h}^{-1}$. Water table and DNAPL interface variations were measured and recorded using pressiometric probes (VEGAWELL 52 model).

\subsubsection{Surfactant foam flushing}

Another cell, also pre-treated by up-welling PT using the technique described above, was used to test SF flushing technology on DNAPL impregnated sands at the bottom of the aquifer. The SF flushing treatment consisted in injecting a surfactant solution and gas using the SAG method described in previous articles (Maire et al., 2015; Maire and Fatin-Rouge, 2017). Injection was carried out between 9 and $9.5 \mathrm{~m}$ 

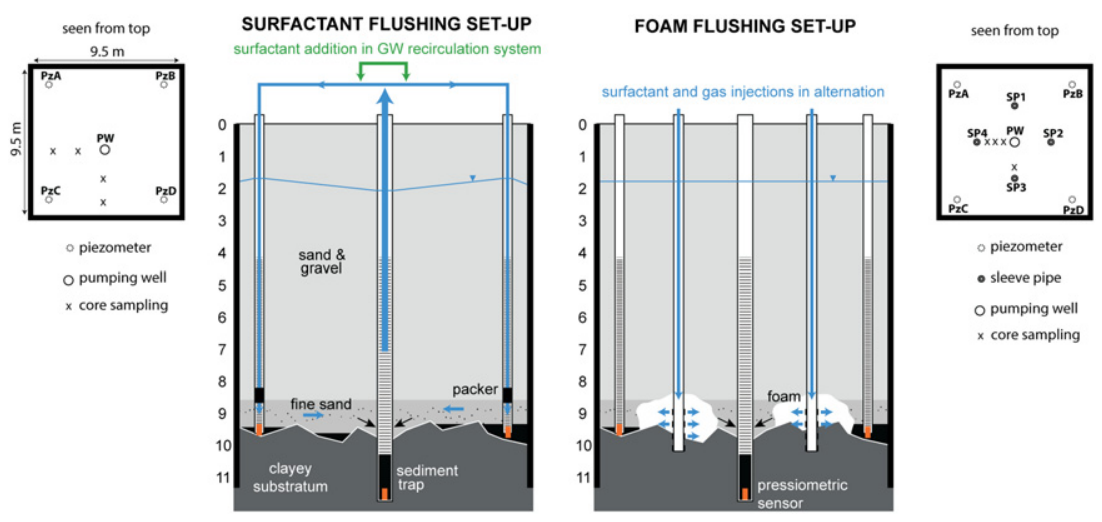

Fig. 2. Field set-up for surfactant flushing with GW recirculation and SF flushing.

bgs, which corresponds to the DNAPL impregnated sands layer, using four sleeve pipes and packers. The sleeve pipes were situated around the recovery well, about $3 \mathrm{~m}$ from it. Water table and DNAPL interface were measured as reported in Section 2.4.1.

\section{Results and discussion}

\subsection{Lab-scale results}

\subsubsection{Immiscible mobilization}

3.1.1.1. $\gamma_{o w}$ change with surfactant concentration. Fig. 3 reports the effect of surfactant concentration on the lowering the $\gamma_{\text {ow }}$ between DNAPL and artificial groundwater. The $\gamma_{\text {ow }}$ was $34.3 \pm 4.8 \mathrm{mN} \mathrm{m}^{-1}$ in the absence of surfactant. Increasing surfactant concentration led to a logarithmic $\gamma_{\text {ow }}$ decrease $\left(\gamma_{\text {ow }}(C)=-22.951 * \log (C)+1.2945, \mathrm{R}^{2}=0.99\right)$. For $C=1.5 \%$, the $\gamma_{\text {ow }}$-value could not be measured by the pendant drop method, because it was too low. It was approximated to be $1 \mathrm{mN} \mathrm{m}^{-1}$.

3.1.1.2. DNAPL extraction as a function of DHSS concentration. Fig. 4 reports the DNAPL saturation after flushing with different surfactant concentrations.

The injection of 10 PV of artificial groundwater without surfactant was equivalent to the PT recovery process. A large amount of DNAPL was released from the DNAPL saturated soil during the recirculation of 4 first PV of water. After that, recovery did not change. At the end of this injection, DNAPL saturation ( $S_{\text {DNAPL }}$ ) was $0.33 \pm 0.03$. This residual saturation agrees with typical residual saturation observed after a PT treatment, known to be inefficient for total DNAPL removal (Interstate Technology and Regulatory Council, 2002).

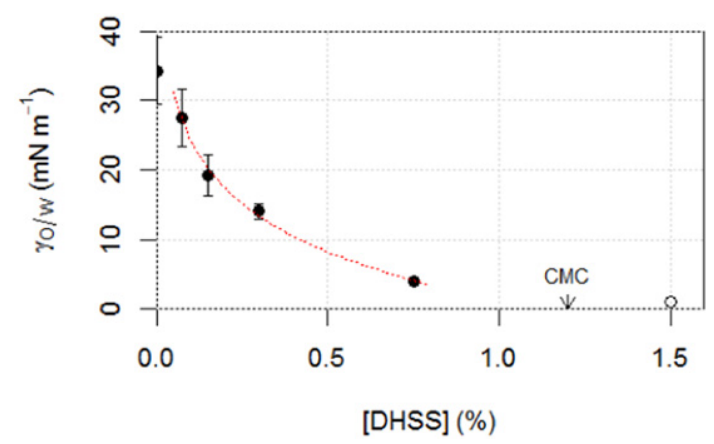

Fig. 3. Variations of $\gamma_{\text {ow }}$ with DHSS concentration in lab-tests. The dotted line is the logarithmic fit of experimental data. $\gamma_{\text {ow }}$ could not be measured accurately for [DHSS] $=1.5 \%$.
Increasing surfactant concentration further decreased $\mathrm{S}_{\mathrm{DNAPL}}$. For each concentration increase, the organic phase was released during the first 4 to $6 \mathrm{PV}$ of solution injected then recovery did not further evolve. Experimental data was successfully fitted by using a logarithmic function: $\gamma_{\text {ow }}(C)=-0.0704 * \log (C)+0.2264\left(R^{2}=0.99\right)$. According to that logarithmic function, at CMC value, $\mathrm{S}_{\mathrm{DNAPL}}$ should be lowered to 0.23 without increased dissolution.

Finally, the injection of a solution with a surfactant concentration of $1.5 \%$ (above CMC) did not significantly improve DNAPL recovery ( $\mathrm{S}_{\mathrm{DNAPL}}$ $=0.22 \pm 0.04$ ). Moreover, significant DNAPL dissolution began since the outflow's aqueous phase was observed to change from clear to milky brown.

A linear relationship $\left(S_{\text {DNAPL }}=0.0034 * \gamma_{\text {ow }}+0.2169, \mathrm{R}^{2}=0.99\right)$ was observed between $\gamma_{\text {ow }}$ and equilibrium $S_{\text {DNAPL }}$ (Fig. 5). According to this relationship, $\mathrm{S}_{\mathrm{DNAPL}}$ is not expected to decrease below 0.217 when $\gamma_{o w}=0$. However, theoretically, at $\gamma_{o w}=0$, all capillary forces trapping DNAPL droplets should be released, and only solution flow and buoyancy forces should act on droplets mobilization. In this experimental set-up, since the injection is descendant and DNAPLs are denser than water, we would expect a total theoretical DNAPL recovery at $\gamma_{\text {ow }}$ $=0$. Previous work reported the complete removal of PCE from a soil column mostly by immiscible mobilization using a surfactant solution (Pennell et al., 1996, 1994). $\gamma_{\text {ow }}$ was $0.09 \mathrm{mN} \mathrm{m}^{-1}$. However, to reach such a low $\gamma_{\text {ow }}$, surfactant concentrations above CMC were used in that work. Authors report that it led to an increase of DNAPL solubility from $200 \mathrm{mg} \mathrm{l}^{-1}$ in water to $71,720 \mathrm{mg} \mathrm{l}^{-1}$. Authors also observed the formation of a macroemulsion. In these conditions, it can hardly be compared to mobilization when surfactant concentration is below CMC since other mechanisms occur. We assume that the difference we observed here is due to the fact that surfactant solution was injected in oil-wet soil, initially fully saturated with DNAPL. Hence surfactant

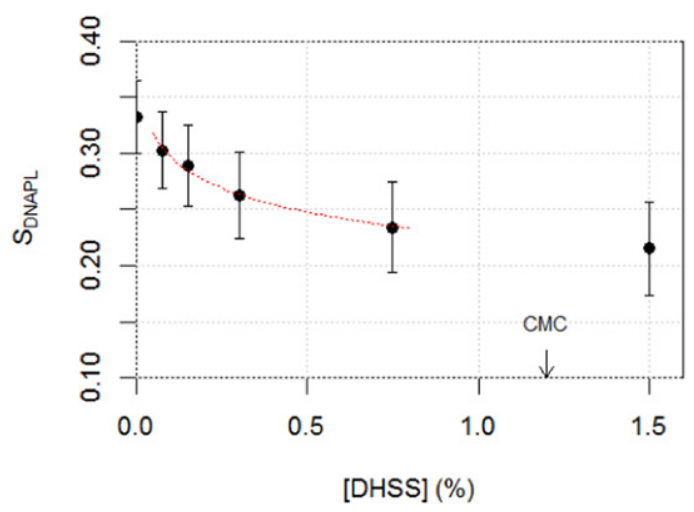

Fig. 4. Equilibrium DNAPL saturation after flushing with different surfactant concentrations. Dotted line is logarithmic fit of experimental data. 


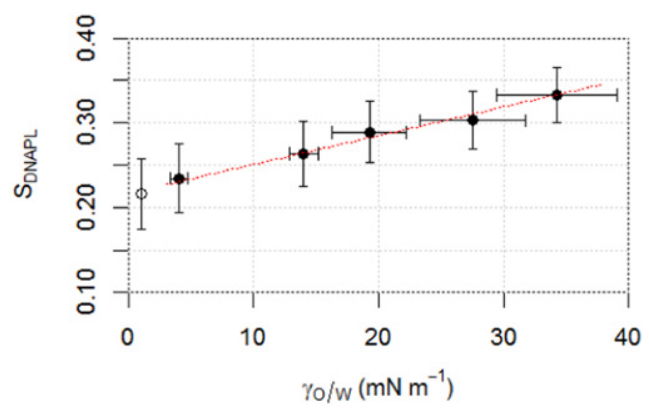

Fig. 5. Relationship between $\gamma_{\text {ow }}$ and equilibrium DNAPL saturation.

solution must have percolated through the soil with a fingering behavior $\left(\mu_{\text {water }}<\mu_{\text {DNAPL }}\right)$ and not all the DNAPL was contacted by surfactant. This preferential surfactant solution flow was visually observed by other authors (Jeong, 2005) who studied TCE mobilization by surfactant solution in a glass micromodel $\left(\gamma_{\mathrm{ow}} \sim 5 \mathrm{mN} \mathrm{m}^{-1}\right)$. Because of the preferential pathways, they were not able to lower DNAPL saturation below $41 \%$ after 25 PV of solution injected.

For every surfactant concentration assessed, capillary, bonding, and total trapping numbers $\left(\mathrm{N}_{\mathrm{Ca}}, \mathrm{N}_{\mathrm{B}}\right.$ and $\mathrm{N}_{\mathrm{T}}$ ) were calculated (Table 1 ). The capillary number relates viscous to capillary forces:

$\mathrm{N}_{\mathrm{Ca}}=\mathrm{U} \mu /\left(\gamma_{\mathrm{ow}} \cos \theta\right)$

where $U$ is the Darcy's velocity of solution, $\mu$ the solution's viscosity and $\theta$ the contact angle between the two phases on the solid. Solution viscosity was considered to be water's viscosity. The bonding number relates buoyancy to capillary forces:

$\mathrm{N}_{\mathrm{B}}=\Delta \rho \mathrm{gkk}_{\mathrm{rw}} /\left(\gamma_{\mathrm{ow}} \cos \theta\right)$

where $\Delta \rho$ is the density difference between the two phases, $\mathrm{g}$ is the gravitational constant, $\mathrm{k}$ is the intrinsic permeability of porous medium and $\mathrm{k}_{\mathrm{rw}}$ is the relative permeability of the aqueous solution. The relative permeability for water was retrieved from desaturation curves on this soil (Colombano et al., 2017). The total trapping number relates viscous and buoyancy forces to the capillary forces acting to retain DNAPL droplets. Considering the experimental set-up used at the lab scale, the following relationship holds:

$\mathrm{N}_{\mathrm{T}}=\left|\mathrm{N}_{\mathrm{B}}+\mathrm{N}_{\mathrm{Ca}}\right|$

Pennell et al. (1996) report $\mathrm{N}_{\mathrm{Ca}}$ being 0.4 to 4.7 -fold the value of $\mathrm{N}_{\mathrm{B}}$ depending on surfactant formulation. Here, $\mathrm{N}_{\mathrm{Ca}}$ is 1.5 to 2.5 -fold superior to $\mathrm{N}_{\mathrm{B}}$ indicating that viscous forces dominate over buoyancy forces during the experiments. Pennell et al. (1996) showed that a critical value for $\mathrm{N}_{\mathrm{T}}$ (between $2 \times 10^{-5}$ and $5 \times 10^{-5}$ ) had to be reached to initiate DNAPL mobilization. However, their experiments started with an initial $S_{\text {DNAPL }}$ of 0.11 (1.0 here); consequently, a correlation between $\mathrm{N}_{\mathrm{T}}$ and mobilization at initial $\mathrm{S}_{\mathrm{DNAPL}}>0.11$ cannot be determined from their work. They report $S_{\text {DNAPL }}$ to decrease to 0.10 at $\mathrm{N}_{\mathrm{T}} \sim 3 \times 10^{-5}$, to 0.04 at NT $\sim 10^{-4}$ and to 0.01 at $\mathrm{N}_{\mathrm{T}} \sim 1 \times 10^{-3}$. Here $\mathrm{N}_{\mathrm{T}}$ increased by 40 -fold with surfactant concentration up to $2.15 \times 10^{-4}$. However, $\mathrm{S}_{\mathrm{DNAPL}}$ only decreased from 0.33 to 0.22 in the meantime. The final

Table 1

Capillary, bonding, total trapping numbers and DNAPL saturation for lab-scale experiments.

\begin{tabular}{lllllll}
\hline [DHSS] (\%) & 0 & 0.075 & 0.15 & 0.3 & 0.75 & 1.5 \\
$\mathrm{~N}_{\mathrm{Ca}} \times 10^{-6}$ & 3.68 & 4.46 & 6.58 & 8.93 & 31.3 & $125^{\mathrm{a}}$ \\
$\mathrm{N}_{\mathrm{B}} \times 10^{-6}$ & 1.49 & 2.11 & 3.34 & 5.15 & 20.6 & $90.0^{\mathrm{a}}$ \\
$\mathrm{N}_{\mathrm{T}} \times 10^{-6}$ & 5.17 & 6.57 & 9.92 & 14.1 & 51.8 & $215^{\mathrm{a}}$ \\
$\mathrm{S}_{\text {DNAPL }}$ & 0.33 & 0.30 & 0.29 & 0.26 & 0.23 & 0.22 \\
\hline
\end{tabular}

a Values for $C_{S}=1.5 \%$ were estimated for $\gamma_{\mathrm{ow}}=1 \mathrm{mN} \mathrm{m}^{-1}$. saturation is higher than that observed by the authors for similar $\mathrm{N}_{\mathrm{T}}$. Hence it seems to confirm the assumption that DNAPL recovery was here limited by preferential flow of surfactant solution.

By modifying the surfactant formulation, better results could be obtained. Some authors used polymer to increase viscous pressure and sweeping efficiency of surfactant solutions to improve DNAPL mobilization (Longino and Kueper, 1999; Martel, 1998). However, our goal here was not to obtain total DNAPL removal since assessment of zero-valent iron injection was planned after this treatment. The objective was to assess whether it was economically interesting to inject a low amount of surfactant before iron injection. Indeed, it did release of a part of the trapped DNAPL and reduce the amount of iron needed. Lab results show that surfactant solution at a concentration near CMC should be used on the field since it would be able to maximize DNAPL recovery while not dissolving or emulsifying DNAPL. However, since the final DNAPL saturation only decreased with $\log \left(\mathrm{C}_{\mathrm{S}}\right)$, economic efficiency decreases while treatment objectives increase. Therefore, a lower DHSS concentration of $1 \%$ was recommended to be used on the field.

\subsubsection{Comparison to other flushing treatments}

This process was compared to results obtained for other flushing treatments assessed by authors with the same soil and contaminant. Fig. 6 reports the different experiments. Each one is represented by two points: saturation at the beginning and at the end of the experiment. Experiments are ordered on the $y$-axis according to the surfactant consumption. There were slight protocol variations between the experimental series, which are reported in Table 2.

As stated before, PT does not require surfactant and reduced $\mathrm{S}_{\text {DNAPL }}$ from 1 to 0.33 . The high amount of DNAPL being removed with no surfactant makes this process to seem economical. However, it is inefficient to recover DNAPL droplets trapped in narrow pores by capillary forces. This spread DNAPL residual contaminates groundwater for decades. Hence, PT cannot be considered to be a complete treatment technology. This treatment was used in field preparation, to remove high amount of DNAPL with reduced cost, before more technical treatments were assessed.

Immiscible mobilization by lowering $\gamma_{\mathrm{ow}}$ with surfactant concentration below CMC, further reduced $S_{\text {DNAPL }}$ by $33 \%(0.22)$ during IM1. This technology did not require much surfactant $\left(0.10\right.$ to $0.46 \mathrm{~kg} \mathrm{~kg}^{-1}$ of recovered DNAPL) but it was not able to bring DNAPL saturation below 0.22 with these experimental conditions. Results show that viscous forces are too low to allow for good contact with DNAPL, leading to fingering (Jeong and Corapcioglu, 2005) and irreducible DNAPL saturation. Moreover, despites its ability to mobilize DNAPL with low surfactant consumption, this technology did not receive much interest because gravity will make the released DNAPL to sink. That limits its use to sites where subsurface characterization ensures that uncontrolled mobilization of DNAPL can be contained. Here, the accurate topological characterization of the site geology in the source zone area showed the presence of an impervious clayey substratum on which

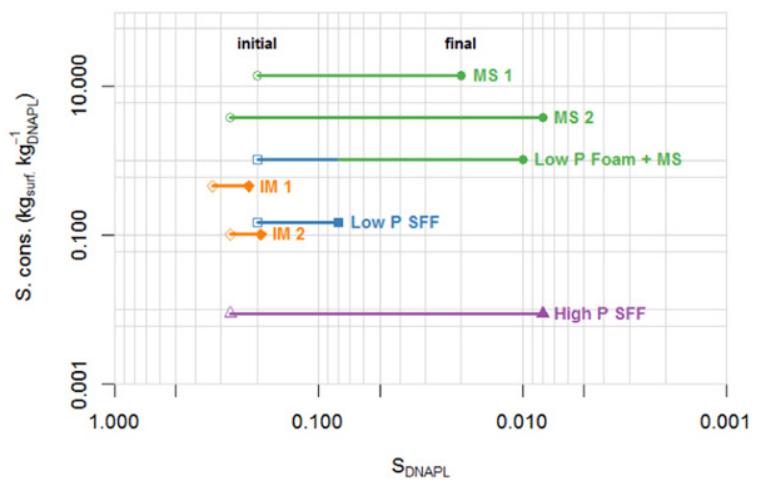

Fig. 6. Remediation technology performances. 
Table 2

Experimental conditions.

\begin{tabular}{|c|c|c|c|c|c|c|}
\hline Experiment & Column orientation & Surfactant & Injection mode & $\begin{array}{l}\text { Injection } \\
\text { velocity } \\
\left(\mathrm{m} \mathrm{s}^{-1}\right)\end{array}$ & $\begin{array}{l}\nabla \mathrm{P} \\
(\mathrm{kPa} \\
\left.\mathrm{m}^{-1}\right)\end{array}$ & Reference \\
\hline $\begin{array}{l}\text { Micellar solubilization (MS) } \\
\text { MS1 }\end{array}$ & 1D, horizontal & Tergitol 15-S-9 10\% & No foam, constant flow & $5.0 \times 10^{-5}$ & $1.3^{\mathrm{a}}$ & $\begin{array}{l}\text { (Maire and Fatin-Rouge, } \\
\text { 2017) }\end{array}$ \\
\hline MS 2 & $\begin{array}{l}\text { 1D, vertical, ascendant } \\
\text { flow }\end{array}$ & Tergitol 15-S-9 5\% & No foam, constant flow & $6.7 \times 10^{-4}$ & $17^{\mathrm{a}}$ & (Maire et al., 2015) \\
\hline Low P SFF + MS & 1D, horizontal & $\begin{array}{l}\text { DHSS 4\% then Tergitol } \\
15-S-910 \%\end{array}$ & SAG, constant pressure & Variable & 90 & $\begin{array}{l}\text { (Maire and Fatin-Rouge, } \\
\text { 2017) }\end{array}$ \\
\hline $\begin{array}{l}\text { Immiscible mobilization IM } \\
1\end{array}$ & $\begin{array}{l}\text { 1D, vertical, descendant } \\
\text { flow }\end{array}$ & DHSS, $1.2 \%$ & No foam, constant flow & $1.3 \times 10^{-4}$ & $3.1^{\mathrm{a}}$ & This work \\
\hline IM 2 & $\begin{array}{l}\text { 1D, vertical, ascendant } \\
\text { flow }\end{array}$ & CAPB/SDS 9:1 0.05\% & No foam, constant flow & $6.7 \times 10^{-4}$ & $17^{\mathrm{a}}$ & (Maire et al., 2015) \\
\hline Low P SFF & 1D, horizontal & DHSS $4 \%$ & SAG, constant pressure & Variable & 90 & $\begin{array}{l}\text { (Maire and Fatin-Rouge, } \\
\text { 2017) }\end{array}$ \\
\hline High P SFF & $\begin{array}{l}\text { 1D, vertical, ascendant } \\
\text { flow }\end{array}$ & CAPB/SDS 9:1 0.05\% & $\begin{array}{l}\text { Premade foam } \mathrm{FQ}=95 \% \text {, } \\
\text { constant flow }\end{array}$ & $6.7 \times 10^{-4}$ & 1020 & (Maire et al., 2015) \\
\hline PT & $\begin{array}{l}\text { 1D, vertical, descendant } \\
\text { flow }\end{array}$ & No surfactant & No foam, constant flow & $1.3 \times 10^{-4}$ & $3.1^{\mathrm{a}}$ & This work \\
\hline
\end{tabular}

a Approx., calculated from permeability.

DNAPL accumulated. Hence, we decided to assess this remediation technology at field scale.

Higher surfactant concentrations were used at the lab scale to assess “micellar solubilization" technology (MS1 \& MS2). Low residual saturations were reached for MS1 (0.008), but it required a lot of surfactant $\left(3.9 \mathrm{~kg} \mathrm{~kg}^{-1}\right)$. Moreover, those results were obtained in a favorable set-up. The 1D column was held vertical and injection was ascendant, meaning that surfactant solution was forced to circulate through the DNAPL even if the DNAPL sunk. This treatment was also assessed with horizontal injection to better mimic field conditions (MS2). At surfactant contact, DNAPL residual quickly sunk down to the bottom of the cell, where it formed a DNAPL pool. This is a known drawback of micellar solubilization: the dissolution process is the most efficient at high surfactant concentration $\left(C_{S}\right)$, but it also extremely reduces $\gamma_{o w}$, causing an uncontrolled downward migration of DNAPL. After the DNAPL pool formed, a surfactant solution was circulating at the top of the cell. The exchange surface between DNAPL and the surfactant solution was limited to the pool surface. Hence, dissolution efficiency was much lower: surfactant consumption was $14 \mathrm{~kg} \mathrm{~kg}^{-1}$ to reach a DNAPL saturation of 0.02 . A review of data from field applications even reports surfactant consumptions up to $200 \mathrm{~kg} \mathrm{~kg}^{-1}$ of DNAPL removed (Atteia et al., 2013). This costly and risky process was not assessed at the field scale.

Different types of foam were assessed. The first type was premade before injection. They required a high pressure gradient (1.02 $\mathrm{MPa} \mathrm{m}^{-1}$ ) to propagate into the soil but DNAPL extraction was excellent (Final $\mathrm{S}_{\text {DNAPL }}=0.008$ ) with the lowest surfactant consumption $\left(0.009 \mathrm{~kg} \mathrm{~kg}^{-1}\right)$. This is by far the most efficient process. Other advantages were: 1 ) no excessive DNAPL dissolution since $C_{S} \sim C M C, 2$ ) low volume of solution at outflow and 3 ) fast and controlled foam propagation with low sensitivity to soil anisotropy (Khatib et al., 1988).

However, such high pressure gradients cannot be used in shallow soils since it may lead to soil fracturing and heaving. SAG foam was used next since its propagation required a lower pressure gradient. Unfortunately, process performance was shown to be directly dependent on injection pressure, demonstrating that viscous pressure is a critical parameter for DNAPL recovery (Maire and Fatin-Rouge, 2017). Foam injected with a pressure gradient of $90 \mathrm{kPa} \mathrm{m}^{-1}$ brought DNAPL saturation down to 0.08 with a surfactant consumption of $0.15 \mathrm{~kg} \mathrm{~kg}^{-1}$. Surfactant consumption was similar to the immiscible mobilization process while the lower final DNAPL saturation was reached when foam was used. As visually observed in micromodels (Jeong and Corapcioglu, 2005), lowered $\gamma_{o w}$ is not sufficient for DNAPL removal. The viscosity of the injected fluid should also be high to limit preferential flow and increase DNAPL removal. Foam does not only reduce $\gamma_{\text {ow }}$. In addition, pore throats blocked by lamellae give foam an important apparent viscosity (up to billion times the gas viscosity alone). High viscosity foam is needed for high DNAPL removal; however, it requires high pressure to propagate. Therefore, low $\nabla$ P SFF cannot be considered as a self-sufficient process to achieve remediation since final $S_{\text {DNAPL }}$ is still high.

A hybrid technology was then developed for shallow soils where high pressure foam cannot be used (Maire and Fatin-Rouge, 2017). It combines two treatments. First, low pressure foam is injected to efficiently recover a major part of the DNAPL. Then, a micellar solubilization treatment is applied by injecting high concentration surfactant into the volume of soil occupied by foam. It led to a final DNAPL saturation of 0.01 , like micellar solubilization. It gets the benefits of the foam process listed above. Moreover, during the second part of the treatment, foam was demonstrated to enhance micellar solubilization. Gas bubbles created in pore bodies during foam injection reduced the DNAPL relative permeability. It prevented droplets from falling, since as shown by Pennell et al. (1996), gravity forces have less effect on DNAPL mobilization when permeability is reduced. Since DNAPL did not sink, it maintained a high exchange surface with the solubilizing solution. DNAPL dissolution was fast and efficient. Surfactant consumption was $>10$ times lower $\left(1.04 \mathrm{~kg} \mathrm{~kg}^{-1}\right)$ than for micellar solubilization treatment.

The downside of the foam technology is the critical tuning needed for injection parameters and formulation to get the highest foam viscosity while maintaining the injection pressure below soil's maximal admissible pressure (Maire et al., 2015; Maire and Fatin-Rouge, 2017). Both are required to ensure the best DNAPL extraction without risk of soil fracturing and heaving.

The foam process was selected to be assessed at field-scale. Low pressure SFF was used (SAG). However, the selected process to complete DNAPL elimination was not micellar solubilization. As for the field cells where immiscible mobilization was assessed, we decided to complete COC's removal using zero valent iron.

To summarize, experimental data for mobilization experiments were added to figures from a previous publication (Maire and FatinRouge, 2017) (Fig. 7). These and previous results from authors are plotted against a theoretical curve (Lake, 1989). It relates final $S_{\text {DNAPL }}$ to capillary number. Though different treatment processes were involved, all those points (except hybrid treatment where micellar solubilization was involved) can be joined and show the same trend as the theoretical curve. Final DNAPL saturation shows to be a logarithmic function of capillary number. The shift observed between the theoretical curve and experimental data is due to different pore size distribution (Lake, 1989). First PT treatment is ineffective at reaching DNAPL saturation below 0.3. It is unable to release trapping forces in the finer pores. Residual saturation can be lowered by lowering $\gamma_{\text {ow }}$ (increase $\mathrm{N}_{\mathrm{Ca}}$ ), but residual 


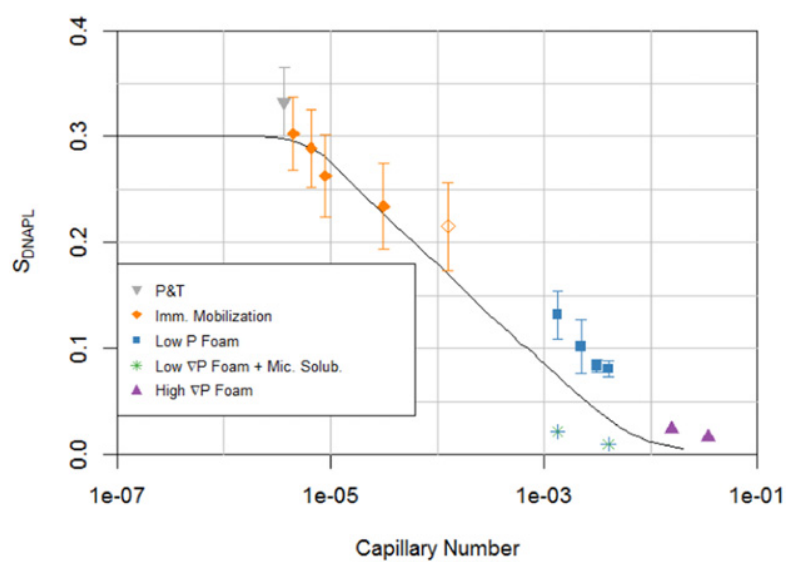

Fig. 7. $\mathrm{S}_{\mathrm{DNAPL}} v s . \mathrm{N}_{\mathrm{Ca}}$ for mobilization experiments using water alone, surfactant solution, low and high $\nabla \mathrm{P}$ foams and low $\nabla \mathrm{P}$ foam completed by micellar solubilization. Curve is theoretical data from (Lake, 1989).

saturation remains above 0.2 . To further increase $\mathrm{N}_{\mathrm{Ca}}$ and decrease $\mathrm{S}_{\mathrm{DNAPL}}$, with comparable $\gamma_{\mathrm{ow}}$ reduction, the viscosity of the injected fluid must be increased. Low pressure foam with moderate viscosity can lower $S_{\text {DNAPL }}$ to 0.08 . To reach almost complete DNAPL removal, more viscous foam can be injected, lowering $S_{\text {DNAPL }}$ to 0.01 . When shallow soil is contaminated, low pressure foam can be followed by micellar solubilization to reach 0.01 saturation.

\subsection{Field-scale results}

\subsubsection{Flushing with groundwater and with surfactant solutions}

Fig. 8 describes the evolution of $\gamma_{\text {ow }}$ and the water/DNAPL interface altitude in the recovery well as a function of the volume of water reinjected (VP).

Pore volume was estimated at $180 \mathrm{~m}^{3}$ considering a measured porosity of $20 \%$. The initial DNAPL thickness in the cell was around $55 \mathrm{~cm}$ above clayey substratum (average thickness of the 4 piezometers and the recovery well). The estimated amount of DNAPL in the cell was $10 \mathrm{~m}^{3}$.

According to lab results, $6.6 \mathrm{~m}^{3}$ of DNAPL should have been pumped during up-welling PT. However, only $1 \mathrm{~m}^{3}$ of DNAPL was recovered. One cause could be the aclinic substratum topography. Indeed, preliminary geophysical data and drillings showed high frequency variations in the substratum altitude. The difference of clayey substratum altitude between the four corners of the cell was about $30 \mathrm{~cm}$. Moreover, the recovery well was not located in the deepest part of the cell. Therefore, it is difficult to be sure that all DNAPL was pumped as DNAPL could have moved preferentially near to piezometer $B$ where the clay altitude was the lowest and which was further from the recovery well than A or $\mathrm{D}$ piezometers (Fig. 2 ).

A first injection of $200 \mathrm{l}$ of surfactant was done at $0.08 \%$ volumetric concentration for $1.7 \mathrm{PV}$. The concentration was lower than lab recommendations because of high surfactant viscosity in field

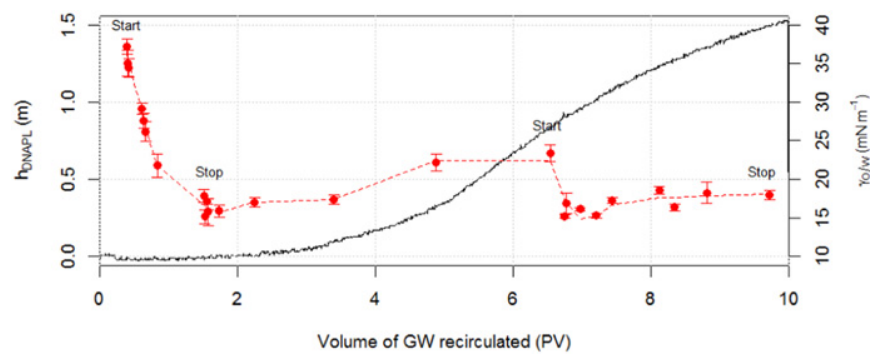

Fig. 8. Evolution of DNAPL height in the recovery well (full line) and interfacial tension (dashed line) during field SEAR. conditions, which limited its injection flow. $\gamma_{\text {ow }}$ decreased from 37.2 to $15 \mathrm{mN} \mathrm{m}^{-1}$ whereas no significant evolution of DNAPL thickness was observed in the recovery well. $\gamma_{\text {ow }}$ was lowered more than expected from lab work for this surfactant concentration, probably because of differences in ionic composition of water. After surfactant injection, recirculation was maintained. One PV later after surfactant injection stopped, $\gamma_{\text {ow }}$ slowly increased. It was attributed to degradation/dilution/adsorption processes. However, at the same time, DNAPL thickness started to increase continuously in sediment trap.

The inertia observed between the end of surfactant injection and the beginning of DNAPL accumulation in the sediment trap can be explained by preferential flow of surfactant solution in the cell. Even if packers had been installed in the lowest part of the 4 piezometers, those were screened from the bottom up to $4 \mathrm{~m}$ depth and filling materials between tube and aquifer allowed surfactant to pass through upper aquifer layer, which was more permeable. This low surfactant solution velocity in the deepest layer might haves caused two effects: 1) $\gamma_{\text {ow }}$ decreased more slowly in the deepest strata than the upper one and DNAPL might not have been totally contacted by surfactant solution. 2) Water velocity was too low in the deepest strata to push the released DNAPL ahead to the recovery well.

A second surfactant injection phase (200 l) was carried out at $0.5 \%$ volumetric concentration after $6.5 \mathrm{PV}$ recirculation, to theoretically lower $\gamma_{\text {ow }}$ to $8 \mathrm{mN} \mathrm{m}^{-1}$ (Fig. 3). $\gamma_{\text {ow }}$ immediately decreased after starting this new injection. However, $\gamma_{\text {ow }}$ did not decrease below $15 \mathrm{mN} \mathrm{m}^{-1}$. This value was identical to the first injection, even if surfactant concentration was doubled. Inefficiency of the second injection to lower $\gamma_{\text {ow }}$ could be due to a decrease of water's salinity during recirculation. Initially, water between 0 and $-8 \mathrm{~m}$ had an average conductivity of $1.4 \mathrm{mS} \mathrm{cm}^{-1}$, while average conductivity was $3.3 \mathrm{mS} \mathrm{cm}^{-1}$ between -8 and $-10 \mathrm{~m}$. Water was pumped around $-9 \mathrm{~m}$. Hence, water reinjected initially had a higher salinity helping for $\gamma_{\text {ow }}$ reduction. Then, because of water recirculation in all cellule height, salinity could have been averaged by mixing. This decrease of salinity in the flushed layer could have decreased the efficiency of surfactant flushing test.

After 10 PV, DNAPL thickness in recovery well has continuously increased up to $1.5 \mathrm{~m}$ above the initial height. It represents 351 of DNAPL accumulated in the sediment trap. The surfactant flushing test had to be stopped after $10 \mathrm{PV}$, but the DNAPL thickness in the recovery well was still increasing.

As the second surfactant injection was launched while the effect of the first trial had not finished, the effect of the second injection cannot be clearly discriminated from the effect of the first injection. Hence, we might suppose that the 351 of DNAPL recovered were only due to the first $200 \mathrm{l}$ of surfactant injected. The surfactant consumed would be in that case: $3.12 \mathrm{~kg} \mathrm{~kg}^{-1}$. But for all reasons described in the above discussion, it cannot be clearly established that all surfactant flushed the entire volume of impregnated soil and that all DNAPL released was captured by the recovery well. Hence, this consumption is probably overestimated.

At the end of the surfactant flushing test, no DNAPL was observed in the injection wells. However, soil cores that were drilled in the cell revealed the presence of DNAPL droplets at sampling points (Fig. 2).

Laboratory results predicted a residual $S_{\text {DNAPL }}$ of 0.27 if $\gamma_{\text {ow }}$ decreased to $15 \mathrm{mN} \mathrm{m}^{-1}$. Theoretically, $0.6 \mathrm{~m}^{3}$ of DNAPL were expected to be released and accumulated near the recovery well. However, only 35 l were collected ( $1.2 \%$ of the expected amount). This amount is probably underestimated since tests had to be stopped though DNAPL was still accumulating in the sediment trap. However, it seems hardly credible that it could have reached $0.6 \mathrm{~m}^{3}$.

This low recovery probably has the same causes as the delay between $\gamma_{\text {ow }}$ decrease and DNAPL accumulation. In addition, another hypothesis could be that significant DNAPL volume could have been released by interfacial tension decrease but, as for PT, released residual might have turned into pools in topographic recesses. 
Finally, methodologic differences between lab- and field-scales could explain moderate success on the field. Lab experimentation was performed in 1D with recent pollution of sieved and disturbed soil. Even though permeability was similar, porosity was higher than for undisturbed soil. Hence, capillary forces trapping the DNAPL were lower and the later might have been easier to mobilize, but it should not have impacted results to such an extent and, as stated before, numerous factors changed when upscaling from a 1-D model soil column to a 3-D pilot scale in real conditions.

The high frequency variation of clayey substratum could be a limit of the test and of the surfactant flushing application. More technical limitations (bad control of solution flow) could be addressed with an adapted injection set-up.

\subsubsection{Flushing with surfactant foams}

In this cell, the estimated amount of DNAPL initially in place was $8.3 \mathrm{~m}^{3}$. During up-welling PT, $7.6 \mathrm{~m}^{3}$ was recovered. Fig. 9 shows how the pressiometric probe signals changed in the recovery well during the foam injection test. The probes signals seem to be correlated with the different injection phases (liquid and gas) and with the injection cycles. Probe signal recordings showed varying water table and DNAPL interface height during injections that then stabilized until the next injection cycle. The same trend was observed in every piezometer.

The variations in pressure measured by sensors seem to indicate foam formation. Indeed, those sensors measure the water pressure head at two depths to monitor the water table and DNAPL heights (based on density). Since the foam is less dense than water the pressure above the sensor should decrease when it reaches the recovery well. So, pressure sensors should register decreases in water table and DNAPL height. We assume that is what we observed here in the recovery well. Indeed, the foam injection in tube A during day 1 did influence the water table signal briefly but did not influence the DNAPL height signal. Therefore, we assume that foam had not reached the recovery well yet, and that only non-stabilized gas had. By contrast, during day 2 , the injection in pipe $C$ caused a substantial pressure reduction as measured by the two sensors. We concluded that foam had reached the recovery well since the very low foam density $\left(\sim 100 \mathrm{~kg} \mathrm{~m}^{-3}\right)$ strongly affects the pressure sensors measurements. The way the signal slowly returned

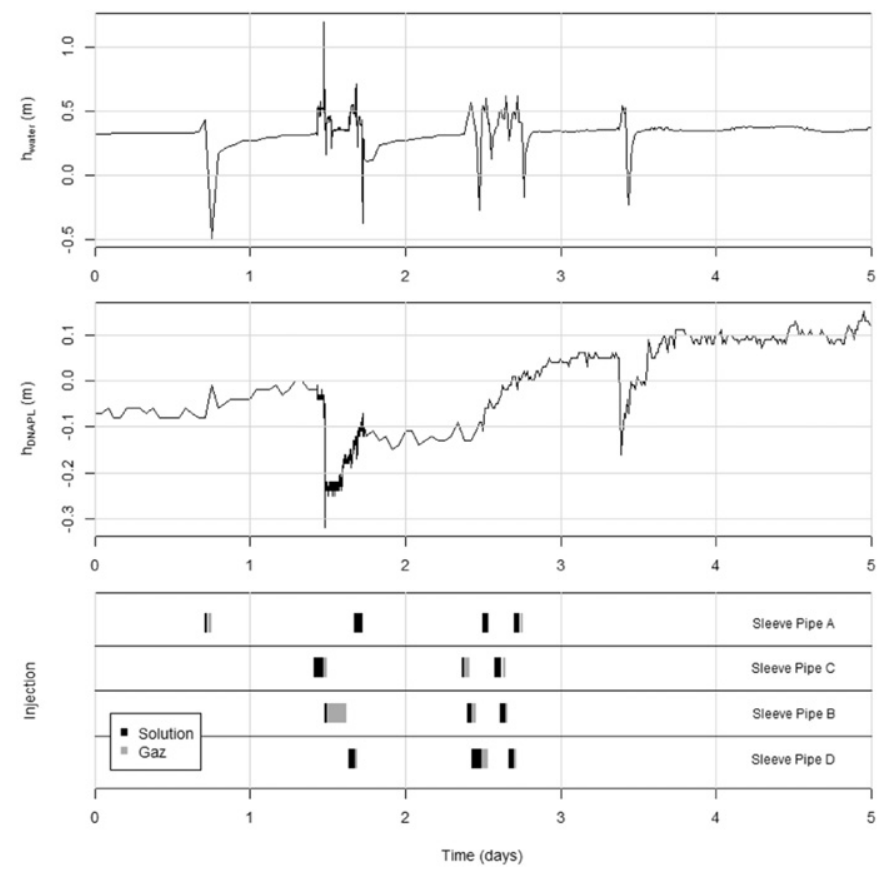

Fig. 9. Variation of the water table level and DNAPL interface level in the recovery well during the foam injection test. The spike during day 3 is due to water injection for pipes cleaning. to the baseline between days 2 and 3 could indicate foam destabilization in wells and/or DNAPL accumulation. When injections started again on day 3 , the pressure recorded by the deepest sensors gradually increased. At the end (day 5), the pressure sensed by the deepest sensor was higher than the initial pressure. We assume that this is because of the presence of DNAPL in the recovery well. However, a mix of DNAPL, water and foam must coexist in the well, and because of the foam's low density, we assume that the amounts of DNAPL calculated from the pressure measurements are substantially underestimated. Therefore, it appears that pressure measurements were not pertinent to quantify mobilized DNAPL during SFF. Those measurements should be confirmed by direct measurements of DNAPL heights using bailers.

In the cell used to assess surfactant flushing, no foam was injected, only solution. There, pressure data did not show significant water table variations. This emphasizes the assumption that the signal peaks observed here are due to gas and foam reaching the wells. These data are also correlated with visual observations of foam exiting wells during foam injection.

Sleeve pipes were drilled half way between the cell's walls and the recovery well (Fig. 2). Since foam is known to develop radially around injection wells, DNAPL was pushed by foam not only to the recovery well but also to the cell's corners. Even if pressure measurements are not pertinent enough for quantitative measurement, pressure sensors indicated that DNAPL height increased by $15 \mathrm{~cm}$ in PzA, $1 \mathrm{~cm}$ for PzB, and $6 \mathrm{~cm}$ for PzB and PP. That agrees with substratum topography. PzD and PzA were the deepest points known in the cell. So, this indicates that DNAPL accumulated at the deepest points of the cell. The sleeve pipes positioning was not optimal for DNAPL gathering in the central recovery well.

Moreover, for technical reasons, it was not possible to inject into all four sleeve pipes simultaneously to gather DNAPL in the recovery well and piezometers. We injected into the sleeve pipes two by two. That means that mobilized DNAPL movement could not be controlled to make it converge to extraction points. It probably moved back and forth as injections happened in different sleeve pipes. These set-up flaws should be addressed to maximize DNAPL recovery.

In spite of that, we did observe process efficiency in the field. Core soil samples were obtained three weeks after the foam injection test, at various points of the cell. Foam was observed in the soil samples (Fig. 10) and at various depths, specifically in the targeted sand layer but also in the upper sandy gravel layer. This proved that injection with the SAG method successfully formed foam in the fine sand strata that was the treatment's target. The presence of foam in soil three weeks after injection also proved that the foam had a relatively long lifetime in the soil.

Finally, whereas DNAPL droplets were still visible at the bottom of soils cores in the cell treated by surfactant flushing, no DNAPL droplets were seen in the cores drilled in the cell treated by SFF (Fig. 10). This might indicate that the foam was effectively able to push the DNAPL droplets, as observed at the laboratory scale.

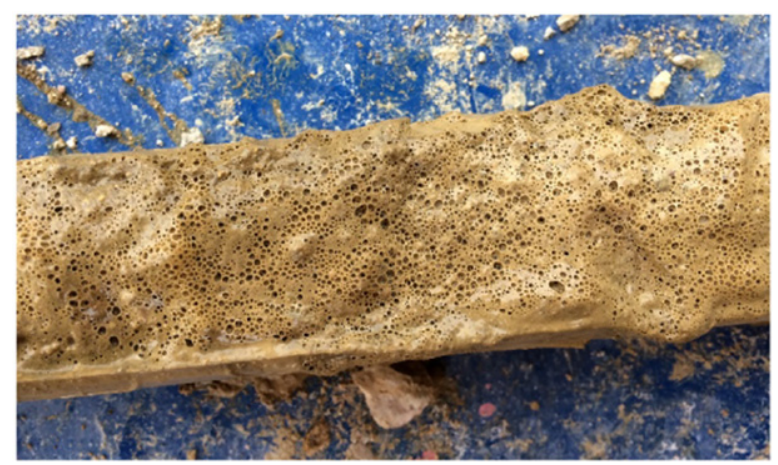

Fig. 10. Soil sampled in the cell three weeks after the injection. 
After this foam injection, we plan zero-valent iron injection. It should benefit from the persistent presence of foam, as was observed for solubilization (Maire and Fatin-Rouge, 2017). Foam gas bubbles reduced permeability in the fine sand strata and the sand and gravel strata above. This should help with targeting iron's delivery to the fine sand strata.

\section{Conclusions}

Immiscible mobilization and surfactant foam flushing for the recovery of DNAPL residual were compared at lab- and field-scales and showed very different behaviors. Well-controlled conditions in lab experiments improved our understanding of the phenomena involved in DNAPL residuals recovery and the associated risks. For immiscible mobilization, despites the benefits of $\gamma_{\mathrm{ow}}$ reduction and decreasing capillary trapping of DNAPL, the substantial residual limit saturation $(\sim 0.2)$ seems hard to overcome in the absence of solubilization. This limit would be the result of fingering and surfactant's preferential flow paths due to its insufficient viscosity. By contrast, surfactant foam flushing showed high efficiency since viscous forces where high while $\gamma_{o w}$ is decreased. The final residual DNAPL saturation decreased with $\log (\nabla \mathrm{P})$ or $\log \left(\mathrm{N}_{\mathrm{Ca}}\right)$.

However, the optimal results obtained in well-controlled conditions do not reflect the DNAPL recoveries in field-tests. The gap between laband field-tests results from poor understanding of local characteristics at field-scale and of technologies used. These demand expertise, specific equipment and modelling. Moreover, field-tests also require time and monitoring to reach optimal conditions.

The use of immiscible mobilization in real conditions requires the preliminary characterization of substratum properties (at least topology and downward hydraulic conductivity) to set recovery wells at the lowest topographic points and anticipate and prevent complications. Moreover, stratification phenomena (geological and hydrodynamical) induce preferential pathways for the flushing fluid and reduce the treatment efficiency. In contrast, SF flushing was shown to be less sensitive to heterogeneity. However, it requires modelling for the propagation of SAG foams to set up an efficient design for the recovery of the displaced DNAPL.

\section{Acknowledgements}

This project was carried out as a part of the SILPHES project funded by the French Environmental Agency (ADEME).

Special recognition is made to Roger Jacquet for his assistance and discussions throughout this project. Additional thanks to Aurélien Triger from Sol Environment for his technical contribution.

\section{References}

Académie des Sciences, 2000. Pollution localisée des sols et sous-sols par les hydrocarbures et solvants chlorés. Ed TEC \& DOC.

Ahn, C.K., Kim, Y.M., Woo, S.H., Park, J.M., 2007. Selective adsorption of phenanthrene dissolved in surfactant solution using activated carbon. Chemosphere 69:1681-1688. http://dx.doi.org/10.1016/j.chemosphere.2007.06.018.

Ahn, C.K., Kim, Y.M., Woo, S.H., Park, J.M., 2008. Soil washing using various nonionic surfactants and their recovery by selective adsorption with activated carbon. J. Hazard. Mater. 154:153-160. http://dx.doi.org/10.1016/j.jhazmat.2007.10.006.

Ahn, C.K., Woo, S.H., Park, J.M., 2010. Selective adsorption of phenanthrene in nonionicanionic surfactant mixtures using activated carbon. Chem. Eng. J. 158:115-119. http://dx.doi.org/10.1016/j.cej.2009.12.014.

Atteia, O., Del Campo Estrada, E., Bertin, H., 2013. Soil flushing: a review of the origin of efficiency variability. Rev. Environ. Sci. Biotechnol. 12:379-389. http://dx.doi.org/ 10.1007/s11157-013-9316-0.

Bertin, H.J., Apaydin, O.G., Castanier, L.M., Kovscek, A.R., 1998. Foam flow in heterogeneous porous media: effect of crossflow. Soc. Pet. Eng. 4. http://dx.doi.org/10.2118/ 56009-PA.

Blaker, T., Aarra, M.G., Skauge, A., Rasmussen, L., Celius, H.K., Martinsen, H.A., Vassenden, F., 2002. Foam for gas mobility control in the Snorre field: the FAWAG project. SPE Reserv. Eval. Eng. 5:317-323. http://dx.doi.org/10.2118/78824-PA.
Butler, E.C., Hayes, K.F., 1998. Micellar solubilization of nonaqueous phase liquid contaminants by nonionic surfactant mixtures: effects of sorption, partitioning and mixing. Water Res. 32:1345-1354. http://dx.doi.org/10.1016/S0043-1354(97)00360-6.

Cazaux, D., Colombano, S., Joubert, A., Dumestre, A., Lecuelle, G., 2014. Optimized physical recovery of DNAPL using upwelling technique and geostatistical analysis at large field scale. BATTELLE Chlorinated Conference Proceedings, Monterey, California, USA.

Colombano, S., Davarzani, H., van Hullebusch, E.D., Ignatiadis, I., Huguenot, D., Guyonnet, D., Deparis, J., 2017. Drainage-imbibition tests and pumping of heavy chlorinated solvents in saturated porous media: measurements and modeling of the effects of thermal and chemical enhancement. AquaConSoil Conference, June 26-30 2017, Lyon, France.

Damrongsiri, S., Tongcumpou, C., Weschayanwiwat, P., Sabatini, D.A., 2010. Solubilization of dibutyltin dichloride with surfactant solutions in single and mixed oil systems. J. Hazard. Mater. 181:1109-1114. http://dx.doi.org/10.1016/j.jhazmat.2010.05.129.

Duffield, A.R., Ramamurthy, R.S., Campanelli, J.R., 2003. Surfactant enhanced mobilization of mineral oil within porous media. Water Air Soil Pollut. 143:111-122. http:// dx.doi.org/10.1023/A:1022829204883.

Farajzadeh, R., Eftekhari, A.A., Hajibeygi, H., 2015. Simulation of instabilities and fingering in surfactant alternating gas (SAG) foam enhanced oil recovery. SPE Reserv. Simul. Symp http://dx.doi.org/10.2118/173193-MS.

Hildenbrand, Z.L., Carlton, D.D., Fontenot, B.E., Meik, J.M., Walton, J.L., Taylor, J.T., Thacker, J.B., Korlie, S., Shelor, C.P., Henderson, D., Kadjo, A.F., Roelke, C.E., Hudak, P.F., Burton, T., Rifai, H.S., Schug, K.A., 2015. A comprehensive analysis of groundwater quality in the Barnett Shale region. Environ. Sci. Technol. 49:8254-8262. http://dx.doi.org/ 10.1021/acs.est.5b01526.

Hildenbrand, Z.L., Carlton, D.D., Fontenot, B.E., Meik, J.M., Walton, J.L., Thacker, J.B., Korlie, S., Shelor, C.P., Kadjo, A.F., Clark, A., Usenko, S., Hamilton, J.S., Mach, P.M., Verbeck, G.F., Hudak, P., Schug, K.A., 2016. Science of the total environment temporal variation in groundwater quality in the Permian Basin of Texas, a region of increasing unconventional oil and gas development. Sci. Total Environ. 562:906-913. http:// dx.doi.org/10.1016/j.scitotenv.2016.04.144.

Hirasaki, G.J., Miller, C.A., Szafranski, R., Lawson, J.B., Akiya, N., 1997. Surfactant/foam process for aquifer remediation. Proceedings of International Symposium on Oilfield Chemistry. Society of Petroleum Engineers http://dx.doi.org/10.2118/37257-MS.

Hydraulic Fracturing Technology Technology Evaluation Report.

Interstate Technology and Regulatory Council, 2002. DNAPL Source Reduction: Facing the Challenge. Interstate Technology and Regulatory Council.

Ireland Environmental Protection Agency, 2014. Drinking Water Parameters: Microbiological, Chemical and Indicator Parameters in the 2014 Drinking Water Regulations.

Jeong, S.-W., 2005. Evaluation of the use of capillary numbers for quantifying the removal of DNAPL trapped in a porous medium by surfactant and surfactant foam floods. J. Colloid Interface Sci. 282:182-187. http://dx.doi.org/10.1016/j.jcis.2004.08.108.

Jeong, S.-W., Corapcioglu, M.Y., 2005. Force analysis and visualization of NAPL removal during surfactant-related floods in a porous medium. J. Hazard. Mater. 126:8-13. http://dx.doi.org/10.1016/j.jhazmat.2005.06.015.

Khatib, Z.I., Hirasaki, G.J., Falls, a.H., 1988. Effects of capillary pressure on coalescence and phase mobilities in foams flowing through porous media. SPE Reserv. Eng. 3: 919-926. http://dx.doi.org/10.2118/15442-PA.

Kilbane, J.J., Chowdiah, P., Kayser, K.J., Misra, B., Jackowski, K.A., Srivastava, V.J., Sethu, G., Nikolov, D.T., Hayes, T.D., 1997. Remediation of contaminated soils using foams. L. Contam. Reclam. 5, 41-54.

Kovscek, A.R., Radke, C.J., 2009. Fundamentals of foam transport in porous media. In: Schramm, L.L. (Ed.), Foams: Fundamentals and Applications in the Petroleum Industry. American Chemical Society, Washington, DC:pp. 115-163 http://dx.doi.org/ 10.1021/ba-1994-0242.ch003.

Lake, L.W., 1989. Enhanced Oil Recovery. Prentice Hall.

Lee, M., Kang. H., Do, W., 2005. Application of nonionic surfactant-enhanced in situ flushing to a diesel contaminated site. Water Res. 39:139-146. http://dx.doi.org/10.1016/ j.watres.2004.09.012.

Li, Y., Abriola, L.M., Phelan, T.J., Ramsburg, C.A., Pennell, K.D., 2007. Experimental and numerical validation of the total trapping number for prediction of DNAPL mobilization. Environ. Sci. Technol. 41:8135-8141. http://dx.doi.org/10.1021/es070834i.

Longino, B.L., Kueper, B.H., 1999. Effects of capillary pressure and use of polymer solutions on dense, non-aqueous-phase liquid retention and mobilization in a rough-walled fracture. Environ. Sci. Technol. 33:2447-2455. http://dx.doi.org/10.1021/es980752h.

Maire, J., Fatin-Rouge, N., 2017. Surfactant foam flushing for in situ removal of DNAPLs in shallow soils. J. Hazard. Mater. 321:247-255. http://dx.doi.org/10.1016/ j.jhazmat.2016.09.017.

Maire, J., Coyer, A., Fatin-Rouge, N., 2015. Surfactant foam technology for in situ removal of heavy chlorinated compounds-DNAPLs. J. Hazard. Mater. 299:630-638. http:// dx.doi.org/10.1016/j.jhazmat.2015.07.071.

Martel, R., 1998. Laboratory study of polymer solutions used for mobility control during in situ NAPL recovery. Ground Water Monit. Remediat. 18:103-113. http://dx.doi.org/ 10.1111/j.1745-6592.1998.tb00734.x

Martel, R., Gelinas, P.J., Desnoyers, J.E., Masson, A., 1993. Phase diagrams to optimize surfactant solutions for oil and DNAPL recovery in aquifers. Groundwater 31:789-800. http://dx.doi.org/10.1111/j.1745-6584.1993.tb00852.x.

Muggeridge, A., Cockin, A., Webb, K., Frampton, H., Collins, I., Moulds, T., Salino, P., 2013. Recovery rates, enhanced oil recovery and technological limits. Philos. Trans. R. Soc. A Math. Phys. Eng. Sci. 372. http://dx.doi.org/10.1098/rsta.2012.0320.

National Research Council, 1994. Alternatives for Ground Water Cleanup (Washington, DC)

Oostrom, M., Hofstee, C., Walker, R.C., Dane, J.H., 1999. Movement and remediation of trichloroethylene in a saturated heterogeneous porous medium. 1 . Spill behavior and initial dissolution. J. Contam. Hydrol. 37:159-178. http://dx.doi.org/10.1016/S01697722(98)00153-3. 
Paria, S., 2008. Surfactant-enhanced remediation of organic contaminated soil and water Adv. Colloid Interf. Sci. 138:24-58. http://dx.doi.org/10.1016/j.cis.2007.11.001.

Pennell, K.D., Jin, M., Abriola, L.M., Pope, G.A., 1994. Surfactant enhanced remediation of soil columns contaminated by residual tetrachloroethylene. J. Contam. Hydrol. 16: 35-53. http://dx.doi.org/10.1016/0169-7722(94)90071-X.

Pennell, K.D., Pope, G.A., Abriola, L.M., 1996. Influence of viscous and buoyancy forces on the mobilization of residual tetrachloroethylene during surfactant flushing. Environ. Sci. Technol. 30:1328-1335. http://dx.doi.org/10.1021/es9505311.

Rathfelder, K.M., Abriola, L.M., Singletary, M.A., Pennell, K.D., 2003. Influence of surfactant-facilitated interfacial tension reduction on chlorinated solvent migration in porous media: observations and numerical simulation. J. Contam. Hydrol. 64: 227-252. http://dx.doi.org/10.1016/S0169-7722(02)00205-X.

Robert, T., Martel, R., Conrad, S.H., Lefebvre, R., Gabriel, U., 2006. Visualization of TCE recovery mechanisms using surfactant-polymer solutions in a two-dimensional heterogeneous sand model. J. Contam. Hydrol. 86:3-31. http://dx.doi.org/10.1016/ j.jconhyd.2006.02.013.

Rosen, M.J., 2004. Surfactants and Interfacial Phenomena. 3rd ed. Wiley-Interscience, Hoboken, New Jersey.

Sabatini, D.A., Harwell, J.H., Hasegawa, M., Knox, R., 1998. Membrane processes and surfactant-enhanced subsurface remediation: results of a field demonstration. J. Membr. Sci. 151:87-98. http://dx.doi.org/10.1016/S0376-7388(98)00170-7.

Salehi, M.M., Safarzadeh, M.A., Sahraei, E., Nejad, S.A.T., 2014. Comparison of oil removal in surfactant alternating gas with water alternating gas, water flooding and gas flooding in secondary oil recovery process. J. Pet. Sci. Eng. 120:86-93. http:// dx.doi.org/10.1016/j.petrol.2014.05.017.

Scherer, M.M., Richter, S., Valentine, R.L., Alvarez, P.J.J., 2000. Chemistry and microbiology of permeable reactive barriers for in situ groundwater clean up. Crit. Rev. Microbiol. 26:221-264. http://dx.doi.org/10.1080/10408410091154237.

Shokrollahi, A., Ghazanfari, M.H., Badakhshan, A., 2014. Application of foam floods for enhancing heavy oil recovery through stability analysis and core flood experiments. Can. J. Chem. Eng. 92:1975-1987. http://dx.doi.org/10.1002/cjce.22044.

Stroo, H.F., Leeson, A., Marqusee, J.A., Johnson, P.C., Ward, C.H., Kavanaugh, M.C., Sale, T.C. Newell, C.J., Pennell, K.D., Lebrón, C.A., Unger, M., 2012. Chlorinated ethene source remediation: lessons learned. Environ. Sci. Technol. 46:6438-6447. http://dx.doi.org/ 10.1021/es204714w.

Szafranski, R., Lawson, J.B., Hirasaki, G.J.H., Miller, C.A., Akiya, N., King, S., Jackson, R.E. Meinardus, H., Londergan, J.T., 1998. Surfactant/foam process for improved efficiency of aquifer remediation. Progr. Colloid Polym. Sci. 111:162-167. http://dx.doi.org/ 10.2118/37257-MS.

Taylor, T.P., Pennell, K.D., Abriola, L.M., Dane, J.H., 2001. Surfactant enhanced recovery of tetrachloroethylene from a porous medium containing low permeability lenses. J. Contam. Hydrol. 48:325-350. http://dx.doi.org/10.1016/S0169-7722(00)00185-6.

WHO, 2010. Guidelines for indoor air quality. WHO Guidelines http://dx.doi.org/10.1186/ 2041-1480-2-S2-I1. 